\title{
Challenges of a social enterprise supporting mothers in Hungary
}

\author{
Henriett Primecz ${ }^{\circledR}$ \\ Organizational Behaviour, Corvinus University of Budapest, Budapest, Hungary
}

\begin{abstract}
Purpose - The purpose of this paper is to examine how and to what extent social enterprise can contribute to improving women's life in Hungary.

Design/methodology/approach - The case study was based on a four-month organizational ethnographic study of a café. Participant and non-participant observations were supplemented with interviews with the founder, the manager, visitors and informal conversations with the staff and visitors. Social media communication was also reviewed.

Findings - The empirical results from the organizational ethnography allowed us to gain insights into the impact of the investigated organization on its target group, young mothers, in a post-socialist gender context. The dominant post-socialist gender regime has remained almost entirely untouched and the outcome of the operation of the social enterprise only helped women to accommodate their everyday life to their disadvantaged social situation.

Originality/value - While previous studies have uncovered the dualistic nature of social enterprises, this analysis shows that an award-winning and popular social enterprise in Hungary could nevertheless only minimally influence the social situation of women. In spite of the good intention of the owner, the all-encompassing prescribed gender roles are hardly questioned, and consequently, women's situation hardly ameliorates.
\end{abstract}

Keywords Social enterprise, Gender, Postsocialism, Organizational ethnography

Paper type Research paper

\section{Introduction}

Social inequalities are present in capitalist economies, which are moderated by welfare states: socially and economically vulnerable social groups are supported by state benefits. Social enterprises ideally combine social aims with an entrepreneurial spirit and provide financially sustainable solutions for social problems with enduring enterprises (Ashforth and Reingen, 2014; Defourny and Nysens, 2013; Smith and Besharov, 2017). Social enterprises are supposed to be win-win solutions: they provide care for people in need, while they also operate as small or medium-sized enterprises within a capitalist system. However, there is growing criticism of social enterprises, as they may replace state support and therefore reinforce neoliberal ideology (Driver, 2017; Fougere et al., 2017). While it is obvious that social problems can only partially be solved by well-intended social entrepreneurs not only because of their size and the fact that their social impacts tend to be local and limited (European Commission, 2015) but it is also because of supportive mechanisms from governments and from supranational bodies (such as the European Union or EU) push the large majority of these social enterprises towards neoliberal operations (Dey and Teasdale, 2016; Driver, 2017; Fougere et al., 2017; Teasdale, 2012).

The original aim of social enterprises is usually to achieve certain social goals, and the business side is added later to create a sustainable organization, which then has an economic

The author is grateful to the members of the Corvinus University of Budapest Social Innovation Research Group, especially György Pataki and Julianna Kiss, for their professional support in writing this article.

Funding: This research was supported by the project nr.EFOP-3.6.2-16-2017-00007, titled Aspects on the development of intelligent, sustainable and inclusive society: social, technological, innovation networks in employment and digital economy. The project has been supported by the European Union, co-financed by the European Social Fund and the budget of Hungary.

Received 23 July 2019 Revised 9 December 2019 27 October 2020 8 January 2021 Accepted 16 February 2021 enterprise supporting mothers 
basis from which to provide support for the target group (Defourny and Nyssens, 2008). Target groups can be any vulnerable social group, such as women, people with disabilities or minority ethnic groups. The paper presents a well-known and widely celebrated social enterprise in Hungary as a case study. The main aim of the social enterprise is to support young mothers by providing a mother-friendly and child-friendly space to reduce social isolation. A four-month field study, including participant and non-participant observations, interviews with visitors, the founder and a manager, constitute the empirical base of the analysis. The main research question is how and to what extent this social enterprise can contribute to improving women's life connected to motherhood in Hungary.

The first part of the paper presents the theoretical basis of this study. First, it discusses the phenomenon of social enterprise at an ideological level: how it reinforces neoliberal market ideology by depriving parts of the welfare system from the state and relocates them to social enterprises. The theoretical part also outlines the inner tension of the double aim (social and business) and points out the hybrid form of organizing. While this theoretical problematisation is in focus, it shows the issues that the everyday operations of socially focused business organizations might face. This is followed by a presentation of the methodology. Organizational ethnography was employed for four months, and this generated a single case study. The article concludes that even a well-known and widely celebrated social enterprise has only a moderate and locally limited positive influence on the lives of its target group - in this case, young mothers. It decreases social isolation, but due to societal pressure from post-socialist gender regime, women are trapped in their separated gender role and the social enterprise has little chance to change existing gender order and improve the lives of women.

\section{Theoretical background: social enterprises in capitalism}

Social enterprise is considered as a relatively new concept in Hungary (Kiss and Mihály, 2019; Kiss et al., 2020), and Fougere et al. (2017) show that a large number of articles and public policy discourse often give the impression that it is a panacea for many of the severe problems caused by the capitalist system. Godin (2012) shows that the idea of social innovation had already emerged 150 years ago and it was first associated with socialism and social reform, while today it is more associated with possible solutions of social problems through individual voluntary and entrepreneurial initiatives within capitalist logic, which are in line with practices of new public management (Fougere et al., 2017), and political support for social entrepreneurial initiatives peaked during the Labour government (1997-2010) in the UK (Mason, 2012). While the debate continues regarding the novelty of the concept, some publications concentrate on the controversial expectations built into the concept: social aim and business logic (Ashforth and Reingen, 2014; Driver, 2017; Fougere et al., 2017; Smith and Besharov, 2017; Wry and York, 2017). Influential social enterprise theorists describe the concept as a natural combination of the two forces, or at minimum, it is worth taking on the challenge to pursue two compatible goals (Defourny and Nyssens, 2013; Nyssens, 2015). Other researchers problematise the essence of the concept. Critics are on two different levels: ideology critiques (Fougere et al., 2017; Nicholls and Teasdale, 2017) and organizational level problems and conflicts (Dey and Steyaert, 2010; Driver, 2017; Pache and Santos, 2013; Smith and Besharov, 2017) or both (Dey and Steyaert, 2010; Steiner and Teasdale, 2016; Young, 2009).

Ideology critiques address the question if it is possible to solve social problems with business enterprises. European welfare capitalism has proved to be expensive, as states have high levels of expenditure on solving or at least decreasing, social problems. The possible loss of competitiveness compared to other countries has motivated European states to reduce taxes and social expenditures. This change in public policy was combined with emergence of neoliberal discourse in EU policymaking, and market and civil society was increasingly under pressure to address social problems. The state was, at least partially, replaced by 
enterprises, reinforcing a neoliberal ideology (Dey and Steyaert, 2010; Fougere et al., 2017; Young, 2009). Nicholls and Teasdale (2017) warn stealth neoliberalism under the cover of social entrepreneurship. Steiner and Teasdale (2016) also highlighted that success attracting financial resource to start a social enterprise largely depends on the social entrepreneur's social capital and ability to present the desired image of an "heroic changemaker"; consequently the image of the social entrepreneur largely influences individual success in securing financial capital. In addition, a large proportion of social problems have been created by the neoliberal capitalist system, e.g. low levels of employment of vulnerable social groups, such as mothers with children, people with disabilities and minority ethnic groups, as they are considered less competitive than a more mainstream employee (OECD, 2013). Young mothers with children lose their competitiveness due to their time constraints (especially in contexts characterised by a lack of childcare institutions and family support) (OECD, 2013). At the same time, social enterprises are often portrayed as social innovation, empowering disadvantaged social groups, while, in reality, the success of social enterprises largely depends on the social entrepreneurs' ability to convincingly fit their concept to policymakers' demands (Steiner and Teasdale, 2016).

The organizational level criticism addresses the fact that contradictory organizational goals may create paradoxes. One argument simply states that social impact costs diminish competitiveness or financial pressures force entrepreneurs to compromise their social mission (Pache and Santos, 2013; Smith and Besharov, 2017). The existence of incompatible demands within an organization creates hybrid forms, which might be successful in the shortterm, but it is questionable if they can survive in the long-term (Smith and Besharov, 2017). Very often, distinct values and beliefs are held by different subgroups within the enterprise, which might perpetuate irresolvable conflicts (Pache and Santos, 2013; Smith and Besharov, 2017). While these subgroups hold relatively equal power within the enterprise, both missions can be kept, but when the fragile equilibrium collapses, the survival of the enterprise is questioned. Driver (2017) explored the experiences and struggles of social entrepreneurs, who had a mission to work for a higher purpose, but who had to subjugate themselves to an expanding entrepreneurial ideology, and this created "heroes" in their identity work. Jones et al. (2008) show the narrative work behind the positive self-image. It is unsustainable to expect to become "heroes" for any work not just for social entrepreneurship (Dacin et al., 2011). Interestingly, this leads back to the ideology critiques, which advise that the concept of social entrepreneurship as a whole should be rejected, as it promotes a seductive and powerful ideology or offers a "decaf" resistance (Contu, 2008), which means that it does not solve the social problems of capitalist societies, but creates further problems at the individual level (e.g. burnout) (Dempsey and Sanders, 2010), undermines non-profits at the organizational level and reinforces capitalist ideology at the societal level.

At the practice level, it leads to difficulties in the social enterprises, when they have to prove their financial sustainability after the initial financial injection (Steiner and Teasdale, 2016; Teasdale, 2016). The entire support system for social entrepreneurs is to help them to learn business operations, and training is provided on business planning, entrepreneurship and market knowledge. If the enterprise fails to maintain their activities in the market, the enterprise will be disbanded. It is not even possible to participate in the support mechanisms, when the entrepreneur fails to prove the business idea's marketability (Steiner and Teasdale, 2016). This results in the scenario where ideas which are valuable in social terms might not even get the chance to get started but the ideas which are selected by supporters (projects, investors and the state) are forced to develop in a certain way, which might be less helpful for the target problem, but is financially sustainable. The stated social aim had to comply with funding agencies' explicit expectations to have a better chance of getting support. Due to isomorphism, environmental pressures push organizations a certain way, both competitively and institutionally (Mason, 2012). Often only those enterprises start which eventually might 
be able to survive as "normal" enterprises. Enterprises with strong social aims generally struggle in the market, they might be grant dependent (Giacomantonio, 2017) and their main difficulties are defined as the demand of those with money to spend, reaching their customers and beneficiaries, maintaining their cash flow and paying for the employees. Salaries are rather low at social enterprises and they often require volunteers (Van Sandt et al., 2009).

The demands of being financially sustainable make it very difficult to grow, and social innovation remains at a small scale. It means that social enterprises are typically micro enterprises or small and medium businesses. This has consequences for their social impact, which can be limited and local. To solve social problems at a large scale might be a futile endeavour (Sud et al., 2009). While states and supranational bodies intend to replace welfare systems with social enterprises, they will actually fragment and debilitate social support to vulnerable groups. For example, state and supranational bodies have the means to change gender regimes by introducing supportive mechanism to emancipate women (e.g. childcare institutes, parental leave schemes, gender quotas for corporate boards and universities to break down the horizontal and vertical segregation of jobs, etc.). A social entrepreneur can only operate within the given gender regime, it may only amend oppressive gender practices, and a small social enterprise cannot replace it. Even when the entrepreneur understands the social problem at larger scale, they have no means to influence it beyond their market (Sud et al., 2009). This limited social impact reinforces the harm of the uncontrolled capitalist system.

The difficulty to measure social impact complicates the picture. Nicholls (2018) points out that the lack of established accounting regulation and audit standards for social impact leads to mismatch among competing demands. Social entrepreneur starts the business with predefined social aim and planned social impact, stakeholders' experience of social impact may vary greatly and equally relevantly investors might have alternative judgement of social impact. In practice, though, social impact is measured and investors are to be convinced that social impact has been sufficiently reached.

The situation of social enterprises is particular to post-socialist EU member countries, such as Hungary (Kiss et al., 2020). A prerequisite of joining the EU was to make progress on some social and economic issues. Part of this was to strengthen the presence of social enterprises (Kiss, 2015). The overall weakness of the third sector in this region made it difficult to strengthen social entrepreneurship, although the positive attitude towards capitalist market solutions, in contrast with the old socialist/communist version, helped the popularity of the concept of social entrepreneurship. Still, the role of social enterprises is considered to be marginal in Hungary (Kiss, 2015; Kiss and Mihály, 2019; Primecz et al., 2019), and this defines a research gap. Hungary's unique societal context creates research questions about the social impact and operation of social enterprises.

\section{Methodology}

Organizational ethnography (Czarniawska, 2017; Kostera, 2007) seemed ideal to thoroughly investigate one organization to reveal actual daily practices and to discover the possible discrepancies between intended aims and actual realisation of aims. The researcher kept in mind that, although organizational ethnography provides potentially rich data, it cannot be generalised, as research results are limited to one case. The empirical study was initiated by the researcher and the owner agreed to allow this intensive method in her café. The research aim was discussed and agreed upon between the researcher and the owner, keeping in mind that the research results could be useful for developing the practice of the enterprise and help it reach its social aims. The main research question is how and to what extent this social enterprise can contribute to improving women's life connected to motherhood in Hungary, with the practical focus of the owner as to how their operations could be improved. The researcher was interested in the social impact and if it meant the organization might decrease, even slightly, the gender inequality in Hungary. The owner supported the researcher to 
participate in the everyday functioning of the café, special events and programmes, and she was open when being interviewed. She also encouraged the researcher to interview visitors to the café. Being a small enterprise, there are only a few employees and most of them work on a part-time basis, so they were not interviewed but short informal conversations with them formed part of the research. The owner asked the researchers to fill out a tally sheet about visitors when observing everyday operations at the café to make notes about the participants and write a report on the tally sheet categorising visitors based on gender and age, whenever observing for a minimum of one hour. In addition, the researcher made notes about observable behaviour, parts of conversations and also participated in short conversations with visitors. The visitors were informed about the researcher on social media, where the researcher's photograph and the aim of the research were also announced. This study is to provide detailed account of the field and map the views of different actors as service providers and visitors (Yanow, 2009).

The research took place from September 2018 until December 2018. The research relationship was established by an initial interview and discussion with the owner during the summer of 2018. The researcher spent at least two to three hours each week in the café at different times, including mornings, around noon, afternoon, late afternoon both weekdays and weekends, except Sundays, when the café was only open for private events, e.g. birthday parties. All observation was recorded by field notes. Three open discussions with the owner and two other interviews with the manager were completed, then an in-depth interview, which was recorded and fully transcribed. Eight short interviews were recorded with visitors and fully transcribed, and several other short informal conversations took place, which were not recorded but notes were taken in the field notes. Formal interviews, informal conversations and observational field notes are the basis of analysis. Furthermore, the website and social media of the café were investigated. The researcher signed up to the social media of the café during the research and was kept informed of programmes, menus, events and further news about the social enterprise. The owner used social media primarily to communicate with visitors. The researcher gave detailed feedback to the owner after the data collection was completed (March 2019), and she asked the advice of the researcher as to how the activity of the social enterprise could be improved to have more significant social impact. This article does not include any changes after the feedback session.

The analysis started with the transcribed interviews (owner and visitors) with open coding, and a contrast of opinions about social impact was immediately transparent in connection with the research question. Then, further hand-written field notes were reviewed and these reinforced visitors' points of view. The owner and manager had overlapping approaches to the place and the programmes, although the manager had more practical understanding of social aim, whereas the owner had a more visionary view. Available data on social media did not impact the analysis, for only practicalities were posted (e.g. menus and available programmes) and nothing related to the research question or overall aim of the social enterprise was mentioned.

\section{The Hungarian context}

The ideology of socialism characterised by full employment and the intention erase class differences (Doolan and Cepić, 2018) and to decrease social inequalities, including gender inequalities, resulted in different routes of change in gender relations than in Western Europe and North America. While in the West, bottom-up initiatives resulted in slow changes to gender structures, in Eastern European socialist countries between 1948 and 1989, centralised decision-making urged women to participate actively in the employment market independently of their marital and parental status. The high-employment rate of women compared to the West eventually resulted in a relatively high proportion of women in managerial and leadership positions (Nagy et al., 2016). State socialist citizenship guaranteed 
women's reproductive rights with long periods of financially supported maternity leave and women's right to employment was legally guarantied (Asztalos Morell and Gradskova, 2018).

Although socialist ideology emphasised equality of genders, in practice, women were rarely seen as equal partners, even when they were appointed to senior managerial or political positions (Fodor, 2004; Fodor et al., 2019). This forced emancipation had contradictory consequences; Nagy (2001) points out that women's presence in the labour market and managerial positions was higher in the 1980s than in Western countries but, at the same time, a conservative family policy meant that women were encouraged to take care of the family and children, called as "refamilisation" in literature (Saxonberg and Sirovátka, 2006), instead of being active in the labour market, and this impacted the post-socialist gender order (Nagy et al., 2017). Glass and Fodor (2011) highlight the strong presence of the "motherhood penalty" in Hungarian women's recruitment, hiring and promotion in work organization. In postsocialist discourse, centrally initiated gender mainstreaming is often categorised as an unnatural and harmful legacy of socialist/communist ideology and consequently should be avoided, in line with retraditionalisation/renaturalisation of gender roles (Asztalos Morell and Gradskova, 2018).

The public discourse in Hungary, including men and women in private and large majority of media and political communication, is concerned about family-friendliness and the "natural" gender roles, overemphasising motherhood for women and the breadwinning role for fathers. At the same time, Hungary is among the developed countries which cannot maintain demographic equilibrium in the country, due to the fact that the number of newly born children is far below the number of deaths in the country, a relatively high proportion of women take maternity leave. The average number of children per woman is $1.2-1.5$, slightly lower than the EU average of 1.55; at the same time, the average length of time spent on maternity leave per woman in Hungary is 3.1 years. This long period of maternity leave is derived from the childcare support provided by the state, including six months at $70 \%$ of previous salary (unlimited), 1.5 years at $70 \%$ of previous salary (limited to 206,000 HUF $€$ 560 , approximately $60 \%$ of average pay) and one year at a smaller amount $(28,000 \mathrm{HUF} \sim €$ 77 , approximately $7 \%$ of average pay) (KSH, 2017). This state support is accompanied by a widespread belief that it is in the best interest of the children that their mother stays with them until the age of three. This belief is often supported by experts in the media providing scientific evidence that a child's healthy psychological development is ensured by mothers being available for the children (Kampichler and Kispéter, 2014; Kutrovátz, 2017) and performing intensive mothering (Nagy, 2020). Many mothers also share this ideology, and women are often labelled as selfish or careerist when they return to work before their children are three (Blaskó, 2010; Kutrovátz, 2017).

The relatively long support from the state for parental leave is a legacy of the socialist system. The maternity leave system was introduced in 1967 to encourage an increase in the birth rate, which was decreasing at that time in Hungary. In addition, there was an employment surplus in Hungary (KSH, 2017), and the socialist ideology did not allow unemployment (Doolan and Cepic, 2018), and the support for unpaid female work was in line with socialist feminist ideology. The newly introduced financial support for home childcare became popular, as the double burden of work and children made women's lives difficult, and many wives felt relieved that they could at least free themselves from work outside from home until their children reached the age of three. As motherhood and employment were compatible in a socialist economy (Asztalos Morell and Gradskova, 2018), the long period of maternity leave became an unquestionable right for families (Fodor and Glass, 2018), often at the expense of paid employment after maternity leave, and female employment dropped dramatically after the change of regime in the early 1990s (Frey, 1999), as traditional gender roles had been re-emphasised. Pongrácz et al. (2011) repeatedly proved that Hungarian respondents in European Value Surveys present one of the most traditional attitudes towards 
gender roles; when they are asked about statements such as, "Men should earn money and women should take care of family", the majority opts for a traditional gender division in Hungary (Nagy et al., 2017).

\author{
Social \\ enterprise \\ supporting \\ mothers
}

\title{
Empirical findings: the case of a café inclusive for young mothers
}

The owner of the café was interested in societal issues before starting the enterprise, as she graduated as a cultural anthropologist and had had a chance to live abroad. The first idea about a café inclusive to young mothers with children came when she became a mother: "This young motherhood resulted in 'outsiderness'." She was surprised by the social reaction and felt isolated and experienced hardship when travelling with children. It was difficult to travel from one point to another with a pram and a toddler. She felt excluded from several facets of adult life. She compared her experience with living abroad and stated that, although she was not a mother when she lived abroad, she observed that young mothers were more integrated into society: Hungarian society being less inclusive, the difficulties increase when somebody has children. She also highlighted that she, as an able-bodied person, had difficulties with everyday shopping, crossing the street in downtown with a pram and a toddler: how difficult might it be for a person with disabilities who, e.g. has to move in a wheelchair? With these ideas in mind, she was thinking about how it might be possible to improve the life of parents with small children.

First, she was not considering an enterprise, only to improve her own life, in which, "it seemed to be hopeless to even have a coffee with friends." She reported she was isolated from the rest of the society: everything was different with children. She first started to cooperate with other mothers to make their lives more liveable outside the playground. The first idea was to cooperate and go to a swimming pool together and they could do some sport while other mothers took care of the children, while one mother went to swim for an hour or so. Later they visited each other, and one mother might have some free time to do whatever she wanted to do without her children, e.g. do some cleaning, shopping or simply to have some free time without the child. The cooperation among mothers gave birth to the idea of a café. She did not think about being an entrepreneur herself, just to establish a more stable cooperation among mothers, so instead of hiring a babysitter, other mothers could help and, in return, at another occasion she can give back the favour. The original idea was a reciprocal system among young mothers; this system would give some freedom to mothers, which also helped to overcome social isolation.

The idea was of a place where adults could go with children, a place where nobody disciplines small children who cannot yet behave properly, which means they are loud, they run around and sometimes disturb adults. She dreamt about a place where it was possible to breastfeed without other clients complaining and to change diapers, which would be a safe place for small children, and still comfortable for adults.

Since Hungarian middle-class and lower middle-class families find babysitters unaffordable on a regular basis, the café is also a response to economic restrictions beyond social isolation. While upper-class families in Hungary and middle-class people in wealthier countries prefer to employ regular babysitters or nannies, it is out of the question for most mothers in Hungary. Grandmothers and other female family members provide the most frequent help for young parents in Hungary, but those whose family live far away or are employed or too old have no choice except to remain alone with their children.

After considering possible solutions for young mothers to break out from being socially isolated, it became obvious that an enterprise was needed, which requires capital. This was the first obstacle since the owner was not wealthy and she did not have any money to invest. She did not have the expertise and experience to run such a place, so she decided to consult with people who might have this knowledge. She went abroad, where she had lived before 
and searched for places similar to her imagined café. She talked with owners of cafés. Although there were several rather similar places, she also realised that the social context is different in Hungary. The lack of money (e.g. for babysitters) and the significant obstacles to returning to the employment market for young mothers are the main differences between the countries. Above all, the level of tolerance was different: while it seemed less problematic for young mothers in the investigated country to go to public places with small children, adults in the same situation in Hungary often met with disapproval and even discrimination. It was obvious that the place should not just be a café where adults with children can enjoy themselves but where work integration support programmes could be implemented for young mothers.

The skeleton of the business model was outlined: a tolerant place for adults with children, which provides programmes for children and their parents and, above all, organised work integration programmes for parents who had spent anything from two to ten years out of employment. The strong societal pressure on families, which expects mothers to stay at home with children for several years, and fathers to work more to provide the financial basis of the families, separates female and male career paths, and women need additional support to return to the employment market. In this social and personal situation, the owner saw an open call for social enterprises. She learned about the nature of social enterprises and she realised that it was exactly what she planned: supporting a socially disadvantaged group (young mothers) and providing services to them in a financially self-sustaining manner. The combination of social aims and a financially sustainable business seemed to be feasible and desirable. She applied to the open call together with two other similar young mothers, and they won the start-up capital. They found a place provided by the local government and a significant amount of voluntary work helped to start the café.

The café survived because they received further support from individuals and businesses and they also received very positive publicity, as they won several prizes. The place became popular among young mothers and this led to further positive publicity. Many magazine articles were written about the café in the popular media, and the owner was interviewed in various programmes. This attracted further investments and nonrefundable capital. The owner was active in finding new people and businesses who could help develop the café.

During the time period of observation, the café is often crowded, and the most popular programmes (e.g. cello for babies) are full within a few minutes after being made available for sign up. It is mainly young mothers with children who visit the café, but there are some fathers and some other adults who are free to attend the programmes or simply sit in the café. This is due to the fact that the owner is very active on social media. Many mothers visit the place to have lunch, which is environmentally friendly, relatively inexpensive and designed in a way which is also appropriate for small children. In informal discussions and short interviews, visitors to the café praised the place, highlighting its uniqueness in the town, and that similar places are needed.

Conversations heard during observations varied from toy selections, baby feeding beyond breast-feeding, starting nurseries, child-raising tips, sleeping problems, child illnesses and sometimes comments about fathers, e.g. "Daddy would not believe what an exciting programme we have" were heard. Another time, a child asked his mother where daddy was. The mother responded "He is working. Where else he would be?" Nurseries were discussed by several women and the general tone was that nurseries are harmful for child development, especially when the child attends them too early. Studies were often quoted on this topic: "it has been proven by scientific research that nurseries are harmful before age of three". Separation anxiety is mentioned in connection with this. Rarely the women's conversation did touch upon the topic of returning to work and when it did the most dominant discussion point was that they should not to return to work because of their children's best interest. 
One notable exception was when a rather loud woman explained that she has just arrived from France, where she already works, and she does not "subjugate" herself to child rearing.

Interviews with visitors and informal conversations were similar in tone. The unanimous opinion was that the place is good, as one woman explained "I can come here with a baby, and we do not disturb others". They like the café, because in other places people are less tolerant. They explained frequently that it is ideal for the children, and it is the best choice when it rains or in otherwise bad weather. It was added that it is possible to talk with other mothers, they can share their thoughts and they can see each others' children development, and they can give advice to each other. "It is not only good for kiddies, but for us, mothers, as well" added another woman. The café is usually noisy similarly as a playground, and this might not be pleasant for those who simply want to consume a coffee or beer with a friend or just sit in somewhere and read a book.

The most popular programme was baby cello, and it is difficult to sign up, as the programme is only feasible with a few participants (children and their parents). The enterprise also offers work integration support, free coaching for women who want to return to the employment market, CV development, career advice, legal advice and preparation for job interviews. These services are designed for work integration, as this is the most significant social and economic problem for women with young children, but are less popular among visitors, even though these services provide important social support for the disadvantaged group, young mothers, to fully integrate into society. Based on interviews and informal conversations the visitors had diverse future plans. Some felt relieved that they did not have to work, and they did not plan to return to the work they had before having children, they rather planned radical career changes, which would enable them to spend more time with their families (either being an entrepreneur in the future or simply having a different employment status, such as a freelancer). Some had secure jobs, so they planned to return to their previous position without much help. Finally, some had already worked as a freelancer with a flexible work schedule, and they did not need further help with work integration. Consequently, the free career coaching, which was the raison d'etre for the social enterprise, was significantly underutilised.

\section{Discussion}

The motivation of the owner is clear; her intent is to improve the situation of women, and she and her colleagues prepared a market survey as to whether such a place would be needed and she constantly monitors the needs and satisfaction of the visitors. The very fact that it is a social enterprise makes it unquestionable that the services should meet market demand. The formula is simple, if the café is not viable financially, it will be closed. The organization should be market-driven, client-driven and self-sufficient (Dey and Teasdale, 2016). The popularity of the place is partly derived from the excellently positioned interior design, and the popularity is maintained by constant responsiveness to client needs. This social entrepreneur successfully publicises her enterprise, which fulfils the existing demands of young isolated mothers and addresses an important social problem (Steiner and Teasdale, 2016). The logic of social enterprises supports the social status quo, reinforcing a neoliberal ideology (Dey and Steyaert, 2010; Fougere et al., 2017; Young, 2009) and it this social context that separate gender roles are unquestioned, as the majority of visitors and the general public supports this gender regime, notwithstanding the owner's alternative views on society.

This ideological level reinforcement is coupled with organizational level tension; the actual operation of the enterprise should be maintained financially. Even though the enterprise is supported by the local government with a site provided at reduced price, operational costs should be covered by visitor consumption, which is low due to their financially dependent status and unplannable sporadic support from individual donors and national or 
supranational bodies as the result of successful grant applications. This dependence on grant-giving agencies (Giacomantonio, 2017; Van Sandt et al., 2009) makes it difficult to pursue goals other than those supported. Grant calls and descriptions define what the social goals are, and consequently, it is impossible to pursue alternative social goals than those which are predefined. In this case, the traditional gender division is not questioned by the supporting bodies, and the visitors also take the gender division of labour for granted, as the researcher uncovered during observation and in short interviews with visitors. Although one part of the financial support is to provide work integration preparation for women on maternity leave in the form of free career coaching services, this is not really known by the visitors, and the owner revealed that each free session needs more promotion to be filled than any of the cultural and recreational programmes targeting babies and mothers. Mothers are willing to pay small fees for music sessions for their babies, while free support services which help work integration are largely left unutilised.

Interviewed visitors were largely unaware that the café was a social enterprise and most of them had no information about what social enterprises were. In this case, the eligibility for being social enterprise is ingrained to provide work integration programmes and the owner knew how work integration contributes to social integration, which is her explicit aim. Visitors largely opt for baby cello instead of free career coaching, or they rather have a chat in a baby-friendly café; this is why it is very difficult for the owner to adjust its programmes to the general demand and reach social aims, and the fact that the organization operates as a social enterprise means she has no choice but to comply with the demands of her target group, as any other business venture would (Dey and Steyaert, 2010; Driver, 2017; Fougere et al., 2017). Social aim is to improve young mothers' life and reduce social isolation can be partly achieved by quality cultural and recreational programmes, but in practice the beneficiaries of these programs are mainly babies, and mothers are subjugated to their children's need. Social integration does not happen in such places which are segregated from the large part of the society and young mothers meet similar young mothers, not the rest of the society. The owner's well-intended actions also limited to small scale (Sud et al., 2009), while her dependence on grants and projects limit the social impact of her enterprise (Giacomantonio, 2017; Van Sandt et al., 2009), especially in this social context where local supporters do not question the dominant gender regime.

Real gender change would require society to move away from the post-socialist legacy (Asztalos Morell and Gradskova, 2018; Fodor et al., 2019; Nagy et al., 2017) and instead reflect upon and question traditional gender roles. General attitudes towards men and women (Pongrácz et al., 2011) can be changed and, consequently, attitudes towards work and parenthood can be modified, even within the scale of a small enterprise. This might result in changes in the practice of parenthood and work integration in the longer term. Although it is not realistic to expect fundamental social change as the result of the operation of an enterprise, its present function unintendedly reinforces traditional gender roles rather than changing them. The services of the social enterprise simply make the disadvantageous social situation of women more bearable. The owner is trapped in the given gender regime and although she understands the drawbacks of rigidly separated gender roles, she has no means to influence this either beyond or in her enterprise (Sud et al., 2009).

\section{Conclusion}

Organizational ethnography enabled the researcher to gain insight into the vision of the owner and the actual everyday operation of a social enterprise. Observation was a prominent data collection tool in this situation. Market demand for the service of the enterprise exists, but most visitors to the café do not possess their own income, and consequently cannot afford to pay high prices. This results in the low profitability of the enterprise and the inner tension 
to provide services to the desired social group and marketability is immediately present. The shortage of a workforce in the catering industry also complicates the situation: the salaries for employees are steadily rising. The enterprise provides good quality cultural programmes and environmentally friendly food selections, so the business model is theoretically marketable, but the social and economic context of young mothers in Hungary, from whom the majority of visitors come, are financially dependent or deprived, and this does not allow high prices. The services are popular among young mothers, and the media also helped to publicise the enterprise. Moreover, the idea and the enterprise itself were awarded by several prizes. While the usefulness of the service is unquestionable, its social impact reaches only a limited number of people who need support, and consequently, it leaves the strong conservative gender regime in Hungary untouched. It is not because the owner does not see the societal status of women in contemporary Hungarian society as problematic, but because the enterprise provides only a restricted effect on society as whole. It is, moreover, operating in a social context, where gender equalizing initiatives are not supported by majority of visitors, certain local, private and institutional supporters. Beyond this, experts in EU's mechanism have little understanding of the local contexts. Further social science, including gender studies, research is essential in this region in order to understand what support mechanism might contribute to the bettering of women's social situation in the region. Neither the imitation of programmes successful in certain other social contexts in the EU nor social science ignorant local solutions can produce the desired result. Consequently, more gender research is needed in the region.

\section{ORCID iDs}

Henriett Primecz (Dhttp://orcid.org/0000-0001-6064-2759

\section{References}

Ashforth, B.E. and Reingen, P.H. (2014), "Functions of dysfunction: managing the dynamics of an organizational duality in a natural food cooperative", Administrative Science Quarterly, Vol. 59 No. 3, pp. 474-516, doi: 10.1177/0001839214537811.

Asztalos Morell, I. and Gradskova, Y. (2018), "The gendered subject of postsocialism: state-socialist legacies, global challenges and (re)building of tradition”, in Gradskova, Y. and Asztalos Morell, I. (Eds), Gendering Postsocialism: Old Legacies and New Hierarchies, Routledge, Abingdon, pp. 1-17.

Blaskó, Z. (2010), "Meddig maradjon otthon az anya? Gyremeknevelés szempontjai, [How long a mother should stay at home? - from a child rearing point of view]", Esély, Vol. 3, pp. 89-116.

Contu, A. (2008), "Decaf resistance: on misbehavior, cynicims, and desire in liberal workplaces", Management and Communication Quarterly, Vol. 21 No. 3, pp. 364-379, doi: 10.1177/ 0893318907310941.

Czarniawska, B. (2017), "Organization studies as symmetrical ethnology", Journal of Organizational Ethnography, Vol. 6 No. 1, pp. 2-10, doi: 10.1108/JOE-12-2016-0023.

Dacin, M.T., Dacin, P.A. and Trecy, P. (2011), "Social entrepreneurship: a critique and future directions", Organization Science, Vol. 22 No. 5, pp. 1203-1213, doi: 10.1287/orsc.1100.0620.

Defourny, J. and Nyssens, M. (2008), "Social enterprise in Europe: recent trends and developments", Social Enterprise Journal, Vol. 4 No. 3, pp. 202-228, doi: 10.1108/17508610810922703.

Defourny, J. and Nyssens, M. (2013), "Fundamentals for an international typology of social enterprise models", Voluntas, Vol. 28 No. 6, pp. 2469-2497, doi: 10.1007/s11266-017-9884-7.

Dempsey, S.E. and Sanders, M.L. (2010), "Meaningful work? Nonprofit marketisation and work/life balance in popular autobiographies of social entrepreneurship", Organization, Vol. 17 No. 4, pp. 437-59, doi: 10.1177/1350508410364198. 
Dey, P. and Steyaert, C. (2010), "The politics of narrating social entrepreneurship", Journal of Enterprising Communities: People and Places in the Global Economy, Vol. 4 No. 1, pp. 85-108, doi: 10.1108/17506201011029528.

Dey, P. and Teasdale, S. (2016), "The tactical mimicry of social enterprise strategies: acting 'as if' in the everyday life of third sector organizations", Organization, Vol. 23 No. 4, pp. 485-504, doi: 10. 1177/1350508415570689.

Doolan, K. and Cepić, D. (2018), "Charity's dilemmas: an ethnography of gift-giving and social class in Croatia”, Journal of Organizational Ethnography, Vol. 8 No. 1, pp. 11-24, doi: 10.1108/JOE-032018-0015.

Driver, M. (2017), "Never social and entrepreneurial enough? Exploring the identity work of social entrepreneurs from a psychoanalytic perspective”, Organization, Vol. 24 No. 6, pp. 715-736, doi: $10.1177 / 1350508416665474$.

European Commission (2015), "A map of Social enterprises and their ecosystems in Europe”, available at: https://ec.europa.eu > social > BlobServlet.

Fodor, É. (2004), "The state socialist emancipation project: gender inequality in workplace authority in Hungary and Austria”, Signs: Journal of Women in Culture and Society, Vol. 29 No. 3, pp. 783-813.

Fodor, É. and Glass, C. (2018), "Negotiating for entitlement: accessing parental leave in Hungarian firms", Gender, Work and Organization, Vol. 25 No. 86, pp. 687-702, doi: 10.1111/gwao.12208.

Fodor, É., Glass, C. and Nagy, B. (2019), "Transnational business feminism: exporting feminism in the global economy", Gender, Work and Organization, Vol. 26 No. 8, pp. 687-702, doi: 10.1111/ gwao.12302.

Fougere, M., Segercrantz, B. and Seeck, H. (2017), “A critical reading of the European Union's social innovation policy discourse? (Re)legitimizing neoliberalism”, Organization, Vol. 24 No. 6, pp. 819-843, doi: 10.1177/1350508416685171.

Frey, M. (1999), "Nők és férfiak a munkaeröpiacon [Men and women in the employment market]", in Pongrácz, T. and Tóth, I.G. (Eds), Szerepváltozások. Jelentés a Nök Es Férfiak Helyzetéröl [Changing Roles. Report on Women and Men], TÁRKI, Budapest.

Giacomantonio, C. (2017), "Grant-maximizing but not money-making: a simple decision-tree analysis for social impact bonds”, Journal of Social Entrepreneurship, Vol. 8 No. 1, pp. 47-66, doi: 10.1080/ 19420676.2016.1271348.

Glass, C. and Fodor, É. (2011), "Public maternalism goes to market: recruitment, hiring, and promotion in postsocialist Hungary", Gender and Society, Vol. 25 No. 1, pp. 5-26.

Godin, B. (2012), "Social innovation: utopias of innovation from circa-1830 to the present", Project on the Intellectual History of Innovation, Working Paper No. 11, INRS, Montréal, p. 50.

Jones, R., Latham, J. and Betta, M. (2008), "Narrative construction of the social entrepreneurial identity", International Journal of Entrepreneurial Behavior and Research, Vol. 14 No. 5, pp. 330-45, doi: 10.1108/13552550810897687.

Kampichler, M. and Kispéter, E. (2014), "Public maternalism in the Czech Republic and Hungary: work-family policies in two post-socialist welfare states”, Special Visegrad Issue, Socio.hu, Vol. 4 Special issue in English No. 2, pp. 40-57, doi: 10.18030/socio.hu.2014en.41.

Kiss, J. (2015), "Társadalmi célok, gazdasági tevékenységek, a társadalmi vállalkozások definiciói [Social aims, economic activities, definitions of social enterprises]", Civil Szemle, Vol. 12 No. 1 , pp. 5-24.

Kiss, J. and Mihály, M. (2019), "Social enterprises and their ecosystems in Europe. Country Report Hungary”, available at: http://ec.europa.eu/social/easi.

Kiss, J., Primecz, H. and Toarniczky, A. (2020), "Patterns of inclusion: social enterprises targeting different vulnerable social groups in Hungary", Journal of Social Entrepreneurship, online first, pp. 1-23, doi: 10.1080/19420676.2020.1806101. 
Kostera, M. (2007), Organizational Ethnography: Methods and Inspirations, Studentlitteratur, Lund.

KSH (2017), "50 éve vezették be a gyermekgondozási segélyt (GYES), Korfa.Népesedési Hírlevél [50th anniversary of introduction of maternity leave. Population Pyramid. Demography Newsletter]", Vol. 17 No. 3, available at: www.demografia.hu $>$ index.php $>$ korfa $>$ article $>$ download.

Kutrovátz, K. (2017), "Parental time from the perspective of time pressure, the idea of intensive parenting", Review of Sociology, Vol. 27 No. 4, pp. 20-39.

Mason, C. (2012), "Isomorphism, social enterprise and the pressure to maximise social benefit", Journal of Social Entrepreneurship, Vol. 3 No. 1, pp. 74-95, doi: 10.1080/19420676.2012.665382.

Nagy, B. (2001), Nöi Menedzserek, [Female Managers], Aula, Budapest.

Nagy, B., Király, G. and Géring, Z. (2016), "Work-life balance and the gender regime after the economic transition”, Intersections. East European Journal of Society and Politics, Vol. 2 No. 3, pp. 5-20, doi: 10.17356/ieejsp.v2i3.283.

Nagy, B., Primecz, H. and Munkácsi, P. (2017), "The downturn of gender diversity on boards in Hungary", in Seierstad, C., Gabaldon, P. and Mensi-Klarback, H. (Eds), Gender Diversity in the Boardroom, Palgrave Macmillan, Multiple Approaches Beyond Quotas, Cham, Vol. 2, pp. 205-233.

Nagy, B. (2020), "Mummy is in a call", Use of Technology and Work-Life Balance of Women in Executive Positions. Social Inclusion, Vol. 8, pp. 72-80, doi: 10.17645/si.v8i4.2971.

Nicholls, A. (2018), "A general theory of social impact accounting: materiality, uncertainty and empowerment", Journal of Social Entrepreneurship, Vol. 9 No. 2, pp. 132-153, doi: 10.1080/ 19420676.2018.1452785.

Nicholls, A. and Teasdale, S. (2017), "Neoliberalism by stealth? Exploring continuity and change within the UK social enterprise policy paradigm”, Policy and Politics, Vol. 45 No. 3, pp. 323-41, doi: 10.1332/030557316X14775864546490.

Nyssens, M. (2015), "Innovation sociale et entreprise social : quel dialogues possibles ? Une perspective Européenne [Social innovation and social enterprise: what dialogues are possible? A European perspective]", in Klein, J.L. (Ed.), La Transformation Sociale Pas L'innovation Social, Presses de Université du Québec, Québec, pp. 335-348.

OECD (2013), "Tackling long-term unemployment amongst vulnerable groups", available at: https:// www.oecd.org/cfe/leed/Tackling Long_Term unemployment_WP_covers.pdf.

Pache, A.C. and Santos, F. (2013), "Side the hybrid organization: selective coupling as a response to competing to institutional logics", Academy of Management Journal, Vol. 56 No. 4, August 2013, pp. 972-1001, doi: 10.5465/amj.2011.040.

Pongrácz, T., Molnár, S., Nagy, I. and Pongrácz, T. (2011), "Nemi szerepek és a közvélemény változásának kölcsönhatása [Interactions of gender roles and public opinion]", in Szerepváltozások. Jelentés a Nök Es Férfiak Helyzetéröl. [Changing Roles. Report on Women and Men], TÁRKI-NEFMI, Budapest, pp. 192-206.

Primecz, H., Kiss, J. and Toarniczky, A. (2019), "Diverzitáskategóriák és társadalmi vállalkozások: nemzetközi kitekintés [diversity categories and social enterprises: international review]", Vezetéstudmány / Budapest Management Review, Vol. 50 No. 10, pp. 61-73, doi: 10.14267/ VEZTUD.2019.10.06.

Saxonberg, S. and Sirovátka, T. (2006), "Failing family policy in post-communist Central Europe", Journal of Comparative Policy Analysis, Vol. 8, pp. 185-202, doi: 10.1080/13876980600682089.

Smith, W.K. and Besharov, M.L. (2017), "Bowing before dual Gods: how structured flexibility sustains organizational hybridity", Administrative Science Quarterly, Vol. 64 No. 1, pp. 1-44, doi: 10.1177/ 00018392217750826.

Steiner, A. and Teasdale, S. (2016), "The playground of the rich? Growing social business in the 21st century", Social Enterprise Journal, Vol. 12 No. 2, pp. 201-216, doi: 10.1108/SEJ-12-2015-0036.

Sud, M., Van Sandt, C.V. and Baugous, A.M. (2009), "Social entrepreneurship. The role of institutions", Journal of Business Ethics, Vol. 85, pp. 201-216, doi: 10.1007/s10551-008-9939-1.

\section{Social enterprise supporting mothers}


Teasdale, S. (2012), "Negotiating tensions: how do social enterprises in the homelessness field balance social and commercial considerations?”, Housing Studies, Vol. 27 No. 4, pp. 514-532, doi: 10. 1080/02673037.2012.677015.

Teasdale, S. (2016), "What's in a name? Making sense of social enterprise discourses", Public Policy and Administration, Vol. 27 No. 2, pp. 99-119, doi: 10.1177/0952076711401466.

Van Sandt, C.V., Sud, M. and Marme, C. (2009), "Enabling the original intent. Catalyst for social entrepreneurship", Journal of Business Ethics, Vol. 90, pp. 419-428, doi: 10.1007/s10551-0100419-Z.

Wry, T. and York, J.G. (2017), "An identity-based approach to social enterprise”, Academy of Management Review, Vol. 42 No. 3, pp. 437-460, doi: 10.5465/amr.2013.0506.

Yanow, D. (2009), "Organizational ethnography and methodological angst: myths and challenges in the field", Qualitative Research in Organizations and Management: An International Journal, Vol. 4 No. 2, pp. 186-199, doi: 10.1108/17465640910978427.

Young, D.R. (2009), "Alternative perspectives on social enterprise", in Cordes, J.J. and Steuerle, E. (Eds), Nonprofits and Business, The Urban Institute Press, Washington, pp. 21-46.

\section{Further reading}

KSH (2015), “A kisgyermeket nevelő nők és a munkaerőpiac, Statisztikai Tükör [Mothers with small children and employment market. Statistical Mirror]", available at: www.ksh.hu > docs > hun > xftp > stattukor > kisgyerm_nok_mpiac.

\section{Corresponding author}

Henriett Primecz can be contacted at: henriett.primecz@uni-corvinus.hu

For instructions on how to order reprints of this article, please visit our website: 